The

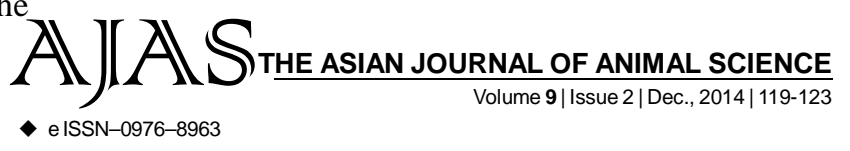

DOI : 10.15740/HAS/TAJAS/9.2/119-123 Visit us | www.researchjournal.co.in $\mathrm{S}^{2}$

RESEARCH ARTICLE.........

\title{
Studies on chemical changes in Shrikhand prepared from safflower milk
}

\author{
H.K. KUTTABADKAR, S.G. NARWADE, S.P. POUL AND V.J. KAMBALE
} H.K. KUTTABADKAR, S.G. NARWADE, S.P. POUL AND V.J. KAMBALE $\ldots \ldots \ldots \ldots \ldots \ldots \ldots \ldots \ldots \ldots \ldots$

Author for Correspondence -

S.P. POUL

Department of Animal Science

and Dairy Science, Vasantrao

Naik Marathwada Krishi

Vidyapeeth, PARBHANI (M.S.)

INDIA

Email: sandippoul@yahoo.com

See end of the article for

Coopted authors'
ABSTRACT...... Shrikhand was prepared from buffalo milk blended with 50 per cent safflower milk and studied for chemical changes during storage. On an average the Shrikhand contained 8.56 per cent fat, 5.81 per cent protein, 43.74 per cent lactose, 0.72 per cent ash and 58.83 per cent total solids and 41.17 per cent moisture. The $\mathrm{pH}$ of Shrikhand stored at $10^{\circ} \mathrm{C}$ was $4.2,4.1,3.9$ and 3.7 while the acidity was $1.42,1.58,1.71$ and 1.85 per cent, on day 14, 28, 42 and 56, respectively. The pH of Shrikhand stored at $30^{\circ} \mathrm{C}$ was declined from 4.3 to 3.6 while acidity was increased from 1.32 to 1.74 per cent within 24 hours. The acceptable Shrikhand stored at $5^{\circ} \mathrm{C}$ has $\mathrm{pH} 3.4$ and acidity 1.83 per cent. The fat content of Shrikhand was decreased during storage. The decrease in fat content was more at higher temperature of storage. The free fatty acids (FFA) content of Shrikhand stored at $5^{\circ} \mathrm{C}$ on day 14, 28, 42 and 56 was 2.81, 3.19, 3.74 and $4.54 \mu \mathrm{g} / \mathrm{g}$, respectively. The increase in FFA of Shrikhand was faster at higher temperature of storage. The protolytic activity (release of tyrosine) was slower at low temperature and faster at higher temperature.

KEY WORDS...... Chemical changes, Safflower milk, Shrikhand, Storage

HOW TO CITE THIS ARTICLE - Kuttabadkar, H.K., Narwade, S.G., Poul, S.P. and Kambale, V.J. (2014). Studies on chemical changes in Shrikhand prepared from safflower milk. Asian J. Animal Sci., 9(2) : 119-123.

ARTICLE CHRONICLE - Received : 01.10.2014; Revised : 18.10.2014; Accepted : 03.11.2014 